\title{
The Nigerian House of Representatives and Corruption, (1999-2011)
}

\author{
Joshua, Segun PhD \\ Department of Political Science and International Relations, \\ Covenant University, Ota, Ogun State \\ joshuasegun2003@yahoo.com, segun.joshua@covenantuniversity.edu.ng
}

Oni, Samuel PhD

Department of Political Science and International Relations, Covenant University, Ota, Ogun State

Doi:10.5901/mjss.2014.v5n2p561

\begin{abstract}
Corruption is one of the major problems contending with the Nigerian socio-political and economic development. Unfortunately, this social ill seems to have defied all remedial measures put in place to curb its expansion. Anchored on elite theory, with heavy reliance on empirical and secondary data, the study examined the Nigerian House of Representative and corruption with a particular focus on 1999-2011. The study found that, constitutionally, the House of Representatives as one of the legislative chambers at the federal level of the Nigerian Government has the mandate to legislate for good governance which includes curbing corruption. However, activities of this chamber over the years revealed that it is indeed an accomplice as far as corrupt practices is concerned in Nigeria. The study, therefore, recommended the need for stiffer punishment for all corrupt public officers among others.
\end{abstract}

Keywords: Corruption, Political Elite, House of Representatives

\section{Introduction}

Corruption has assumed the status of a hydra- headed monster gnawing on the vitals of the Nigerian state. Its tentacles have permeated every facet of the economy. It is interesting to note however, that corruption is not limited to Nigeria. It is indeed evident in all climes, though some countries are more corrupt than others.

It has been observed that corruption is not a recent development; its existence has long history (Wilson, 1999; Usman 2001; Muhammed Undated). Little wonder that Mbeki (1999), Akanbi, (2004), and Ogbonna (2004) among others, averred that corruption is a product of social, political, economic and historical circumstances. The festering tumor of corruption has taken toll on the quality of governance and accountability (Ogbonna, 2004). Corruption is antithetical to progress and development as it breeds inefficiency, incompetence, mediocrity, unethical value, and other base instincts in man such as greed, avarice and rapacity, (Atoyebi and Mobolaji 2004).

Nigeria is endowed with immense human and natural resources, but development has been a mirage (Akinamu, Muhammed, Adeoye, 2008) due to sharp practices prevalent in the country. However, if there is any institution of government that should take the challenge of nipping corruption in the bud or be in the fore-front of anti-corruption crusade, it should be the representatives of the people charged with the duty of law making for good governance among others.

This paper sets out to examine whether the Nigerian Federal House of Representatives has been living up to their constitution mandate of law making for good governance which will translate to cubing corruption.

\section{The Legislature and Corruption: Exploring the Nexus}

Before exploring the nexus of legislature and corruption, it is pertinent to conceptualize the basic concepts in this study. This is because according to Chafe (1994) the primary requirement for discussing a thing is to first understand the actual thing been talked about. From the above postulation, attempt would be made to define the concept. While there is no official definition of the concept, it is broadly defined as the abuse of entrusted authority for private gain (USAID 2005). 
To Lipset and Lenz (2000:114), corruption is "efforts to secure wealth or power through illegal means-private gain at public expense; or a misuse of public power for private benefit". According to Nkom (1982), corruption is the perversion of public affairs for private advantage. It is also conceived as exploitation of public position, resources and power for private gain (Amuwo, 2005; Obayelu, 2007; Ogundiya, 2009; and 2010). In the same vein, Obayelu (2007, cited in Ogundiya, 2010) sees corruption as efforts to secure power, wealth through illegal means for private gain at public expense; or misusing public power for private benefit.

From the various definitions above what seems to be the major thread that weave them together is the fact that, corruption has to do with acquiring wealth through illegal means for private advantage at the expense of the public which is the focrum of this paper.

The concept of legislature has been defined in several ways by scholars. For instance, it is seen as the branch of people with the singular purpose of articulating and expressing the collective will of the people (Okoosi-Simbine, 2010). To Anyaebgunam (2000 cited in Oni, 2013) the concept encapsulates the activities of the organ charged with law making, reversing, amending and repealing for the purpose of advancing the well being of the citizenry that it represents.

Stapenhurst, Ulrich and Strohal (2006) identify; law making, oversight and representational roles as three legislative prongs with which to combat corruption in a democratic society (cited in Alabi and Fashagba 2010). Similarly, Mathekga (2008) postulates that the onus to ensure accountability of the executives and administrative agencies falls squarely on the shoulder of the parliament. John Stuart Mill (cited Anyaegbunam, 2010:7) avers that:

The proper office of the legislature is to watch and control the government; to through the light of publicity on its acts, to compel a full exposition and justification of all of them, which anyone considers questionable and; if the men who compose the government abuse their trust ... to expel them from office.

The above position is not different from that of the former Chief justice of the Federation Katsina Alu. In one of his judgment he reiterated that:

It is also my view that item 60 (a) of the exclusive legislature list read together with section 4 (2) of the 1999 constitution not only imposes a duty on the Federal Government to abolish all corrupt practices, and abuse of power but also impose a duty of making a law through the National Assembly for that purpose (cited in Anyaegbunam 2010:84)

From the above, it is clear that the legislature is a veritable instrument charged with the responsibility of exposing, preventing and enacting laws to address the problem of corruption in a society. Imam and Mustapha (undated) corroborated this that: "the power of the legislature to investigate and expose corruption in Nigeria has its foundation and legitimacy in the constitution and it is a mechanism employ to monitor and keep a watch on the actions of the other arms of government".

It is expected that after proper investigation which will ipso facto culminate in identifying the possible reason(s) for the menace, it is the duty of the legislature to put in place necessary legislation to combat it. In fact, Muhammed (undated) notes that albeit the legislature exercise quite a number of functions from time to time depending on the political system, however, two are central and common to all legislatures in democracy which must be duly performed otherwise such a democracy will be messed up. These are the task of law making and acting as watchdog on behalf of the people whom they represent. Emphasizing the sanctity of these roles Odinga (1994:123) put it more pungently:

If the constitution is the embodiment of the aspirations, ideals and collective will of the people, the parliament is the collective defender and watchdog of the aspiration, ideals and collective will of the people. If the constitution is the social contract between the people and their government, the parliament is the advocate for the people and the arbiter of the national interest. Indeed, if the constitution is (like the Bible, the Quran and other religions treaties) the covenant between the people and their leaders, the parliament is the repository and protector of the oracle, of the political covenant and social contract between the people and their government.

In every society be it democratic or dictatorial only a very few group of people (called elite) call the short. In African context and Nigeria in particular, the political elite criss-crossing not only the national assembly but also in other arms of government and government agencies are noted for corruption. Describing the character of the Nigerian political elite Jega (2010 cited in Nna and Jacob 2012)) argue that there is no denial of the fact that a band of short-sighted and greedy elite, both military and civilian have not only nurtured but have equally converted public treasury and national wealth for private uses.

\section{Corruption in Nigeria: Theoretical Insight}

There is a growing body of literature on the fact that elite group has been a veritable tool for perpetration of corruption 
especially at the level of governance. The work of Joseph (1987, Gyekyke (2003, cited in Seteolu 2005) attested to this fact. In line with the above, the paper adopts elite theory as a framework for analysis. Proponent of elite theory includes vilfredo Pareto (1848-1923), Gaetano Mosca (1858-1941) Roberto Michels (1876-1936), Jose Ortega (1883-1955) among others. The kernel of argument of elite theory is that every society is ruled by a minority that possesses the qualities necessary for its accession to full social and political power. In other words, all societies are made up of two classes of people - a class that rules and a class that is ruled. The first class are very few and performs all political functions, monopolizes power and enjoys the advantage derivable from it, whereas, the second class- the masses is directed and controlled by the first class (Varma 1999).

Elite do not only control and dominate the commanding height of the economy, they equally exercises legal monopoly over the means of coercion, dominate the structures and institutions of politics and also shape the ideological and philosophical direction of the society (Ihonvbere 2009; Ojukwu and Shopeju 2010).

The development of political elite in Nigeria has much to do with the colonial background of the country. After independence, Nigerian elite which took over power from the erstwhile colonial administrations imbibed the culture of self-serving- ethos that is, exploitation of the people and the country for selfish purposes (Ojukwu and Shopeju 2010). The Nigerian elite by their activities have continued to be a cog in the wheel of democracy. This is because they see democracy or governance as a means to an end, they are self centered with tendency for unbridled materialism (Achebe 1983). Consequently, the elite group is not different from its colonial progenitor an instrument of exploitation and a tool for primitive accumulation. It is not surprising that the path to attain and retain power is always fraught with violence without restraint and outright disregard for democratic ethos (Emenuo and Momoh, 1999).

\section{Corruption in Nigeria: An Overview}

Ogbonna (2004) observe that Nigeria was not known to be a corrupt nation in the years before and immediately after independence. There was no record or trace of corruption and indiscipline by the government of Tafawa Balewa let alone controlling it. Unfortunately, the tide changed shortly after then ((Salawu 2008). However, Akinyemi cited in Salawu (2008) seems not to agree with this position. To him corruption in Nigeria started as far back as 1954 as a result of party administration/government. It was then that corruption began to take different forms and magnitude in the Nigerian society. The civilian government that took over from colonial administrations was accused of corruption. The verdict of the first coup plotters attested to this fact. Major Nzeogwu who led the coup emphasized corruption as the reason for military take over and thus reiterated their aim which was: "to establish a strong, united and prosperous nation, free from corruption and internal strife". He further warned that "embezzlement. Bribery or corruption, obstruction of the revolution ... are all offences punishable by death sentence" ( Ogbonna 2004:176).

Subsequently, Ironsi who took over from Balawa as well as Gowon that in turn took over from Ironsi were accused of corruption and indiscipline. Ten (10) of the twelve (12) governors that served under Gowon's regime were dismissed from the Nigerian Army on the ground of corrupt practices when it was overthrown in 1975 by the Muritala/Obasanjo junta (Salawu 2008).

Shagari's regime perhaps, witnessed a colossal rate of corruption. Ifamose (2000) notes that there was about $87.5 \%$ of undetected incidence of corruption in Nigeria during the said time.

General Buhari and Idiagbon that took over power from Shagari could not effectively contain corruption during their twenty months rule. Between 1985 and 1999, General Ibrahim Babangida, Sani Abacha and Abdusalami Abubakar brandished Nigeria as a corrupt and unstable polity through their corrupt practices (Audu 2008).

Analysis of the present Fourth Republic reveals that corruption has grown fat going by crippling cases of corruption in the country from 1999 till date. Alanamu et al (2008) observes that, from the very beginning of the Fourth Republic, the political class has been castigated by numerous press reports for their shady deals in winning party nominations or elections. In short, some of the office- holders were found to be convicted criminals. It is essential to state that because of deleterious nature of corruption quite a number of efforts locally and internationally have been put forward to checkmate its growth. In fact, there is international collaboration against corruption. States have signed treaties and enacted special statute to prevent, control and sanction corruption. Many have established special anti-corruption commissions; Transparency International has been in the fore front in building awareness and act as watchdog. These developments have been supported by a growing output of literature on corruption from the academia (Laver 2010).

Surprisingly with all the aforementioned efforts, corruption is growing stronger at least as far as Nigeria is concerned why? The reason is not far-fetched. Those who suppose to bring Nigeria out of the pit of corruption are already neck-deep in it. Any hope for the country? 


\section{The Nigeria Federal House of Representatives and Corruption 1999-2011}

It has been revealed above that the constitutional mandate of the National Assembly made up of the House of Senate and the Federal House of Representatives is to make law, to promote good governance and curb social vices in the country. This section is an assessment of the activities of the Federal House of Assembly and corruption in Nigeria. Our position in this paper is that, the Federal House of Representatives are not only weak in making laws to check the menace of corruption, the assembly itself is neck deep in corruption as evident from the cases below.

The Fourth Republic in the Federal House of Representatives started on a wrong footing with Salisu Buhari, the speaker accused of falsification of academic claim. He was forced to resign and arraigned before he received presidential pardon. An unnamed member of the House of Representatives in 2002 was alleged to have taken money from the executive to impeach the speaker. Maurice Ibekwe a member of the House was equally alleged to have defrauded a German businessman of N350,000 and 75000. He died in prison while still under trial (Alabi and Fashagba 2010).

Patricia Etteh Nigeria's first female speaker of the House of Representatives was removed for corrupt charges. She became speaker after the House inauguration on June 5, 2007, and was ousted in November of the same year. It was alleged she approved over N600 million for the purchase of body massage machines (Suleiman, 2011). She was equally accused of approving N238 million for renovation of her official quarters without going through due process (Demola 2011).

Bankole took over from Patricia Etteh on $1^{\text {st }}$ November 2006. In his inaugural speech he promised to nudge the House towards a new direction of transparency and accountability (Desmond, 2011). Evidences on ground however, portrayed that he did exactly the opposite. In fact, the House grew from bad to worse under him. In 2008, the House purchased about 380 Peugeot 407 cars. The process for the purchase of the cars for the standing committees of the house generated a huge controversy and protracted crisis in the house to the point that EFCC was alerted (Demola, 2011). In short, Demola (2011) detailed the activities of the speaker (Dimeji Bankole) in the car deals in which the country lost about N2.4 billion to sharp practices. It was noticed that the actual cost of 380 Peugeot 407 cars direct from Peugeot Automobiles Nigeria, PAN, Kaduna was N1,938,000.000, the house leadership paid the supplier N2,359,486,500. A breakdown of the transaction revealed over payment of N417, 486,500. Also, going by the number of cars that were purchased from the manufacturers, the house was entitled to at least 10 percent discount of N235,948,650 which did not reflect in the purchase.

Shortly after then, the speaker (Dimeji Bankole) and the body of principal officers approved the purchase of four units of Range Rover (V8), three units of Mercedes Benz S-600 cars for the speaker and his deputy at N335.5 million. It was discovered that the prices of the vehicles were over inflated. Desmond, (2011) alleged that, there were claims that the contracts for the supply of the cars did not pass through any competitive bidding process before they were awarded to Wadata Global Company. The purchase of Toyota Lexus vehicle for the use of the chief whip at 13.7 million also sparked controversy. There were claims that the vehicle had been supplied at a cost of N12.5 million in the previous month before it was again awarded to another company at the cost of N13.7 million. The car deal scandal was investigated by the EFCC and subsequently indicted all the principal officers of the House for the colossal fraud. Hence the report was sent to the presidency although without being published (Demola, 2011).

Other allegations against the speakership of the House (Dimeji Bankole) include the purchase of LCD 40 inch Samsung LNS 341 for member at $\$ 525,000$ each against the open market price of $\$ 180,00$ per unit. Bankole also authorized the purchase of 400 units of another type of television for $\$ 210 \mathrm{~m}$ instead of $\$ 97.2 \mathrm{~m}$ market price, resulting in a loss of $112.5 \mathrm{~m}$ to country treasury. Other items procured at over-inflated prices include one unit of sharp copier 5316 at $\$ 270,000$ as against open market price of $\$ 160,000 ; 800$ units of Desktop (HP Compaq disc 5700) at $\$ 330,000$ instead of $\$ 160,000$, about $172.8 \mathrm{~m}$ was fleeced from the nation's treasury on computer items alone (Demola, 2011).

But more damaging is the scandal that the House leadership squandered $\$ 9$ billion capital votes, and obtained a \#10 billion loan from the United Bank for Africa which was shared by member to prosecute their election campaigns (Suleiman 2011). Scandalously enough, the loan was to be repaid in bit from the allocation to the House in the 2011 budget, which has been well padded by the legislators. It was the refusal of the president Jonathan to sign the budget that exposed the scandal (Suleiman 2011).

Apart from above avenues for sharp practices, Chris (2011) noted that the lawmakers milk the nation dry through jumbo allowances they approve and pay themselves without following due process. It was also discovered that the embattled speaker Dimeji Bankole at a time after obtaining a loan of $\$ 40$ billion, jacked up his annual salary from \#8million to 400million which was a violation of the approved remuneration package for political, public and judicial 
office holder by the Revenue Mobilization Allocation and Fiscal Commission (RMAFC).

Tambuwal, speaking immediately after he was sworn in as the new speaker of the House (after Bankole failed in his election bid) said "we acknowledge that the dignity and integrity of this House have been called to question" (The News 2011:16 editorial comment). He reminded his colleagues later that:

\begin{abstract}
When we were elected to pursue the entrenchment of probity, accountability and transparency in the conduct of government business as a cardinal legislative agenda, we advised ourselves never to expect that it will be an easy task. Accordingly, I have had cause to occasionally sound a note of warning and reminder that our constitutional task is inescapably hazardous requiring total commitment, diligence, transparency, determination and sacrifice (cited in Anayochukwu 2012:48).
\end{abstract}

Despite these warnings, Farouk Lawan, former member of integrity committee in the House and chairman of the oil subsidy probe committee, admitted collection from oil marketer, Femi Otedola $\$ 620,000$ bribe to delist his two companies Zenon Oil and Gas and Synopsis Enterprises Limited on the list of companies that corruptly got subsidy payments without importing the products (Anayochukwu, 2012).

On law making, it has been observe that the lawmakers have not been leaving to expectation. Ita Enang Chairman House Committee on the rules, disclosed at a time that out of 489 bills introduced into the House, only 187 has been passed leaving about 302 bills hanging. It is alleged that most of the legislators demand gratification before supporting a bill, no matter how important. For example, the lawmakers were alleged to have been given $\$ 10$ million to pass the Petroleum Industry Bill (PIB) (Suleiman, 2011).

Nasiru Dantiye, a former House of Representative member from Jigawa said many of the legislators were ignorant about legislation while those who know were not committed. He added that, most of the lawmakers, most especially in the lower chamber do not know the essence of legislation as they see their business in the House as money sharing (Suleiman, 2011). Hence, the coinage "legislooters" and "representathieves" (Oluokun and Desmond, 2011).

\title{
6. Conclusion and Recommendations
}

It has been made abundantly clear from the above that corruption has greatly eroded the moral value of the Nigeria state especially at the level of governance. Equally, the Federal House of Representatives as it is presently constituted, lack the moral fibres to champion anti-corruption crusade as they have turned themselves, to vampires, feeding fat on the economy at the expense of the masses.

Therefore, it is suggested that the work of legislation should be for the professionals and seasoned political scientists, lawyers, doctors, educationalist, bankers, economists and engineers on part time bases. They should be paid moderate allowance for their efforts after then they can go back to their places of work.

Stiffer punishments should be meted out to corrupt political office holders, like seizure of ill-gotten properties and long prison term for offenders.

Nigeria masses should be sensitized towards holding their leaders accountable.

A separate body should be set up to be in charge of contract award at the various government institutions. The House or any other levels of government and agencies should just make requisition, which will be supplied by the body. The activities of the body should be published monthly for Nigerian citizen to scrutinize.

Political office holders should be compelled to declare their assets at the point of entry and exit from political office.

There is need for societal re-orientation towards appreciating honesty, probity and rectitude while frowning at every form of dishonest behaviour.

Our electoral process should be overhauled in such a way that will pave way for the emergence of credible candidates that have the minds to serve the people.

If the above suggestions are taken into consideration, corruption will be mitigated if not completely eradicated.

\section{References}

Achebe C. (1983) The Trouble with Nigeria, Enugu: Fourth Dimension Publishers

Akanmu A.S.; Muhammed, A.Y, Adeoye, M.N (2008) "Corruption and its Implications for National Development in Saliu, H.A; Jimoh, I.H; Yusuf, N and Ojo, E.O (eds) Perspective on Nation-Building and Development in Nigeria, Political and Legal Issues. Lagos: concept Publications limited.

Akanbi, M.I. (2004). "Corruption, Accountability and Good Governance in Saliu, H.A(ed) Nigeria Under Democratic Rule (1999-2003) Vol. one. Ibadan:University Press PLC 
Alabi, M. O.A and Fashagba, J.Y. (2010) "The Legislative and Ant-corruption Crusade Under the Fourth Republic of Nigeria: Constitutional Imperatives and Practices Realities. International Journal of Politics and Good Governance 1(1, 2): 1-39.

Amuwo, K (2005). The peripheral State: Critical Perspectives on the structure and role of the Public Bureaucracy. J. Dev. Attern. Area Stud., 24(3-4); 119-130.

Anayochukwu, A. (2012) The Rots Deepens" Tell July 2, pp.46-48

Anyaegbunam, E.O (2010) The Legislations Companion. A Handbook for the National Assembly, State House of Assembly and Local Government Legislative Council. Ibadan: Bookbinders.

Atoyebi, G.O. and Mobolaji, H.I. (2004) "Corruption, Accountability and Good Governance in Saliu, H.A(ed) Nigeria Under Democratic Rule, 1999-2003 Vol.one. Ibadan: University Press PLC.

Audu, M.S (2008) "Emerging Issues in the Culture of Corruption in Nigeria: Implication for National Development in Saliu, H.A; Jimoh H.I; Yusuf, N and Ojo, E.O (eds) Perspective on Nation Building and Development in Nigeria Political and Legal Issues. Lagos: Concept Publications Limited.

Chafe, K.S (1994) "The Problematic of African Democracy: Experience from the Political Transition in Nigeria", African Zamani, (special Issue on Heritages and Democratization in Africa). New Series, No 2 (July).

Chris, A (2011). "A Nation's Big Burden" Newswatch May 30, pp.14-19.

Demola, A. (2011) "A house of Fraud" Newswatch May30, pp.14-21.

Desmond, V. (2011) "Bankole"s Dirty legacy" TheNews, May 30, pp.14-18

Emenuo, F.C and Momoh, A (1999) Civil Association. In Oyediran, O and Agbaje, A (eds.) Politics of Transition and Governance 19861996. Great Britain: Russel Press Ltd.

Gyekye, K (2003).Political Corruption: A Philosophical inquiry into a moral Problem in Maduabuchi D. (ed) Philosophy and Politics: Discourse on Values, Politics and Power in Africa. Lagos: Malthouse Press.

Ihonvbere, J. (2009) Leadership and the future of Nigeria. Vanguard 19th March, 2009.

Imam, I and Mustapha, M.A (online n.d).Combating Corruption in Nigeria: the Role of the

Legislative Examined retrieved on 9th August 2012 from http:www.unilorin.edu.ng/publications/imam/corruption\%20mariam \%20t\%20imam.pdf.

Joseph, R.A (1987) Democracy and Pre-bendal Politics in Nigeria: The Rise and Fall of the Second Republic. Ibadan Spectrum Books Ltd.

Laver, R. (2010) "Good News" In the Fight Against Corruption". The Review of Faith and International Affairs, 8 (4) 49-57.

Lipset, S.M. and Lenz, G.M (2000) "Corruptions, Culture, and Markets" in: Lawrence, E. Harrison and Samuel P. Huntington (eds.), In Culture Matter. New York: Basic Book.

Mathekga, R. (2008) The ANC "Leadership Crisis" and the Age of Population in Post Apartheid South Africa. In: Praetorian's J. (ed.). Africa politics: Beyond the Third Wave of Democratization. Cape Town, Juta and Co Ltd.

Mbeki, T. (1999) Address of the President of South Africa to the 9th IACC. Durban, South Africa.October 10-15 online: http://www.transparency.org/iacc9thiacc/papers.htm/Alinks (Retrieved March 1, 2005).

Muhammad, A. (undated) "Legislative Corruption and the Challenge of Democratic Sustenance inNigeria",19992007. Retrieved from http://docs.google.com/views/a:\$9=cache:ixUMJAal8j:www.unilorin on 8/8/2012

Nkom, S. (1982) "Ethical Revelation as an Antidote for Corruption in Nigeria" A Paper Presented at the 1982 NASA Annual Conference held at $A B U$, Zaria

Nna, N.J. and Jacob, O.A (2012) The Institutional Approach to Anti-Graft Crusade: The Case of Independent Corrupt Practices Commission in Nigeria. African Journal of Social Sciences 2(1) 116-129.

Obayelu, A.E. (2007) Cited in Ogundiya I. S. (2010) Corruption: The Base of Domestic Stability in Nigeria. Current Research Journal of Social Science 2(4): 233-241.

Odinga, R. (1994) " Parliamentarians and Corruption and Human Right in AFL Summary Report of Seminar Organized by Africa Leadership Forum in Entebbe Uganda Dec. 12-14. 119-124

Ogbonna, M.I. (2004) "The ICPC and the Fight Against Corruption in Saliu H.A (ed.) Nigeria Under Democratic Rule, 1999-2003 Vol.one. Ibadan: University Press PLC.

Ogundiya I.S (2010) "Corruption: The Base of Democratic Stability in Nigeria. Current Research Journal of Social Sciences 2(4): 233241.

Ogundiya, I. S (2009) Political Corruption in Nigeria: Theoretical Perspective and Some Explanation. The Anthropologist 11(4): $281-292$

Ojukwu, C.C. and Shopeju, J.O (2010) "Elite Corruption and the Culture of Primitive Accumulation in 21 ${ }^{\text {st }}$ Century Nigeria" International journal of Peace and Development Studies 1(2):15-24.

Oluokun, Y. and Desmond, U. (2011) "Crazy Cost of Running Nigeria" The News June 27 pp.15.

Oni, S. (2013) Legislative-Executive Relations in Nigeria in the Presidential System: A Study of Lagos and Ogun States, Nigeria, (19992011). Unpublished PhD Thesis, Department of Political Science and Inernational Relations, Covenant University, Ota.

Okoosi-Simbine, A.T (2010) "Understanding the Role and Challenges of the Legislature in the Fourth Republic: The Case of Oyo State House of Assembly" Nigeria Journal of Legislative Affairs, 3 (1-3):1-27

Salawu, S. (2008) "The ICPC and the War Against Corruption" in Saliu, H.A ;Jimoh, H.I; Yusuf, And E.O Ojo (eds) Perspectives on Nation Building and Development in Nigeria Politics and Legal Issues. Lagos: Concept Publication Ltd.

Suleiman, T (2011) "This House Has Failed" Tell June 6, pp.22-24.

Suleiman, T. (2011) "Between Facts and Fictions" Tell June 27, pp. 44-45 
The News (2011) Editorial Comment. June 2011, pp.16..

US Agency for International Development (2005) "USAID Anticorruption Strategy. Washington, DC: USAID

Usman,Y.B. (2001) Some observations on the historical Perspective.Paper at the National Conference on the Problems of Corruption in Nigeria.Nigeria Institute of Advanced Legal Studies, Abuja, Nigeria. 26-29. March, 2001. Online: http//www/ceddert.com (Retrieved $2^{\text {nd }}$ march, 2005.

Varma, S.P (199) Modern Political Theory, New Delhi: Vikos Publishing House PVTCT.

Wison, R. (1999) International Business and the Return on Integrity, Part at the 9th LACC. Durban, South Africa. October 10-15 online: http://wwwtransparency.org/iacc/9th/iacc/papers. Htm//links(retrieved March, 2005). 
